\title{
Clinical Trial Monitoring Visit Follow-up Letter
}

National Cancer Institute

\section{Source}

National Cancer Institute. Clinical Trial Monitoring Visit Follow-up Letter. NCI Thesaurus.

Code C125443.

A communication from a clinical trial monitor to a clinical trial investig ator following a clinical trial site visit. 